\title{
THE EFFECTS OF DATE STONE MEAL WITH OR WITHOUT ENZYMES SUPLEMNTATION ON GROWTH PERFORMANCE, NUTRIENT DIGESTIBILITY AND ECONOMICAL EFFICIENCY OF RABBITS
}

\author{
M. I. El-Kelawy ${ }^{1}$, A. S. El-Shafey ${ }^{2}$ and H. A. Hamdon ${ }^{3}$ \\ ${ }^{1}$ Department of Poultry Production, Faculty of Agriculture, New Valley University, Egypt. \\ ${ }^{2}$ Department of Animal and Poultry Production, Faculty of Agriculture, Damanhour University, Egypt. \\ ${ }^{3}$ Department of Animal Production, Faculty of Agriculture, New Valley University, Egypt.
}

(Received 5/11/2019, accepted 19/12/2019)

\section{SUMMARY}

\begin{abstract}
A total seventy-five New Zealand White (NZW) weaned rabbits, four weeks age with average body weight $491 \pm 2.77 \mathrm{~g}$, were used to investigate impact of mulitenzymes (EZ) addition to diets containing date stone meal (DSM) on growth performance traits, nutrient digestibility coefficient and economical efficiency of growing rabbits. Rabbit randomly allotted into five experimental groups; each experimental group contains 15 rabbits. The $1^{\text {st }}$ group was fed basal diet and used as control group, which was contained $0 \%$ date stone. Rabbits in the $2^{\text {nd }}$ and $3^{\text {rd }}$ groups were fed diets contained 10\% DSM (low density diets) either without or with EZ addition, respectively. Rabbits in the $4^{\text {th }}$ and $5^{\text {th }}$ groups were fed diets contained 20\% DSM (low density diets) either without or with EZ addition, respectively. Body weight (BW) and feed intake (FI) were weekly recorded and body weight gain (BWG), feed conversion ratio (FCR), production index and economical efficiency were calculated. At the 12 weeks of age, 5 rabbits from each experimental group were taken for the digestibility trial. The results revealed that supplementation of EZ to $10 \%$ DSM diets increased significantly $(\mathrm{p}<0.05) \mathrm{BW}, \mathrm{BWG}$, FI, FCR, economic efficiency and production index compared to control diet. In addition, the groups on the control diet and 10\% DSM with EZ group exhibited significantly $(\mathrm{p}<0.05)$ greater BW, BWG, FI and better FCR, economic efficiency and production index than the other DSM groups, during periods 4-8 and 4-12 weeks of age. On the other hand, the group on $20 \%$ DSM with EZ group showed significantly $(\mathrm{p}<0.05)$ greater BW, BWG, FI, FCR, economic efficiency and production index than the 20\% DSM without EZ group. Enzyme supplementation to $10 \%$ and 20\% DSM diets improved significantly $(\mathrm{p}<0.05)$ nutrients digestibility coefficient compared to control group. From the present results it can be concluded that date stone meal can be inclusion in rabbit diets up to $20 \%$ with adding EZ without adverse effect on rabbit performance and up to $10 \%$ with adding EZ to achieve good performance, economical efficiency comparable to control group, under Egyptian environmental conditions.
\end{abstract}

Keywords: Rabbits, enzymes, date stone meal, growth performance, digestibility coefficient and economic efficiency.

\section{INTRODUCTION}

In Egypt, there is a serious problem of feed shortage for rabbits. There are also, continuous increases in the prices of the traditional feed ingredients (El-Adawy et al., 2005). Rabbits are herbivores and consume high fiber diets with useless (Cheeke et al., 1982).

Dates are strategic for Egypt, which is the world's top producer of the crop, outranking Iran, Iraq and Saudi Arabia. Egypt's production estimated at 1,465,030 tons of dates yearly, or $17.7 \%$ of world production of 7.5 million tons (FAO Statistics, 2014). Depending on variety and quality grade, date fruit contains about 6 to $12 \%$ date stones, which is also known as pits, seeds or kernels of date (Masoudi et al., 2011). Date stone has some advantage, as available in Egypt, is cheap and high in energy content. The chemical compositions of date stone include 3.1-7.1\% moisture, 2.3-6.4\% protein, 5.0-13.2\% fat, 0.9$1.8 \%$ ash and 22.5- 80.2\% dietary fiber. Also, seeds contain high levels of phenolics, anti-oxidants and dietary fibre (Al-Farsi et al. 2007 and Masoudi et al., 2011). At the same time is contain 12.53 MJ metabolisable energy (Al-Hiti, 1978). 


\section{El-Kelawy et al.}

The date stone meal (DSM) is plentiful in Egypt and can give a potential alternative for energy source in feed ingredients of poultry (Tareen et al., 2017). Dietary inclusion of date stone significantly improved the performance and feed utilization of poultry (Tareen et al., 2017). Furthermore, Soliman et al. (2009) reported that DSM might be utilized as a part of rabbit diets without adverse impact on production performance of rabbits. The production performance, feed cost and feed utilization in poultry were improved when included date palm kernel or seed in diets (Zanu et al., 2012 and Abdollahi et al., 2016).

Recently, mulitenzymes (EZ) were utilized in feed industry to improve nutrient digestibility with considerable success (Shaw et al., 2010; Attia et al., 2014a.; b and El-Kelawy and El-kelawy, 2016). The addition of EZ to diet inclusion of DSM has been shown to be beneficial in poultry (Sundu et al., 2006; Al-Saffar et al., 2013, Attia, and Al-Harthi, 2015) and rabbit diets (Soliman et al., 2009; Ibrahim et al., 2010, El-Manylawi and El-Banna, 2013)

In Egypt, the date palm fruit is abundantly produced especially in the Governorate New Valley. In light of these reports, the present study was carried out to investigate impact of enzymes addition to diets containing date stone meal on some growth performance, nutrient digestibility coefficient and economic efficiency of growing rabbits, under Egyptian environmental conditions.

\section{MATERIALS AND METHODS}

The rabbit trial was conducted at Damanhour University, Faculty of Agriculture from Mid-December 2016 to Mid-February 2017 and the chemical analysis was conducted at Assiut University.

\section{Experimental design:}

Seventy-five NZW weaned rabbits, four weeks age and $491 \pm 2.77 \mathrm{~g}$ average body weight, were randomly allotted into five experimental groups, each experimental group contains 15 rabbits distributed among 5 replicates (each containing 3 rabbits in cage). The $1^{\text {st }}$ group was used as control and fed control diet contained $0 \%$ date stone. Rabbits in the $2^{\text {nd }}$ and $3^{\text {rd }}$ groups were fed diets contained $10 \%$ DSM (low density diets) either without or with EZ addition, respectively. Rabbits in the $4^{\text {th }}$ and $5^{\text {th }}$ groups were fed diets contained 20\% DSM (low density diets) either without or with EZ addition, respectively. The experimental basal diet was formulated to meet the nutrient requirements of rabbits according to NRC (1977). Ingredients and chemical analysis of the experimental diets are presented in Table (1).

Date stones were obtained from El-Wadi El-Gaded Governorate and processed according to (AlHarthi et al., 2006) by sun-drying for 72 hours and ground in a heavy-duty high rotation hammer mill to pass through $1 \mathrm{~mm}$. mesh sieve, producing a fine powder suitable for chemical analysis before mixing to the diets. The diets, DSM, barley and wheat bran samples were chemically analyzed for measuring dry matter (DM), crude protein (CP), ether extract (EE), crude fibre (CF), ash and nitrogen free extract (NFE) according to Association of Official Analytical Chemists (AOAC, 2004).

The rabbits were housed in wire cages $(60 \times 55 \times 40 \mathrm{~cm})$ provided with galvanized feeders and automatic nipple drinkers. The experimental diets were offered to rabbits ad libtium and fresh tap water was available to rabbits all the time. Rabbits were kept under the same hygienic and environmental conditions during the experimental period. At 12 week of age, 5 rabbits from each experimental group were taken for the digestibility trial. A total number of 25 male rabbits were housed individually in metabolic cages. Feces and urine were collected separately for four consecutive days. The composite samples of the offered diet and dried feces of each rabbit were chemically analyzed for CP, EE, CF and NFE according to the method of AOAC (2004). During the growing period from 4 to 12 weeks, rabbit $\mathrm{BW}(\mathrm{g})$, BWG (g), FI (g), feed conversion ratio (g feed / g gain) were weekly recorded. Economical evaluation for all experimental rations was calculated as described by Zeweil (1996). Production index was calculated as cited by Attia et al. (2012) as follows:-

$$
\mathrm{PI}=\frac{\mathrm{BW}(\mathrm{Kg}) \times \mathrm{SR}}{\mathrm{PP} \times \mathrm{FCR}} \times 100
$$

Where:

PI $=$ Production Index. BW = Body Weight $(\mathrm{kg}), \mathrm{SR}=$ Survival Rate $(100 \%-$ mortality $) \mathrm{PP}=$ Production Period (days) 
Table (1): Ingredients and chemical analysis of the experimental diets.

\begin{tabular}{|c|c|c|c|c|c|}
\hline Ingredients & $\begin{array}{l}\text { Control } \\
\text { (Diet A) }\end{array}$ & $\begin{array}{c}\text { 10\%DSM } \\
\text { (Diet B) }\end{array}$ & $\begin{array}{c}10 \% \text { DSM+EZ } \\
(\text { Diet C) }\end{array}$ & $\begin{array}{c}20 \% \mathrm{DSM} \\
\text { (Diet D) }\end{array}$ & $\begin{array}{c}20 \% \text { DSM+EZ } \\
(\text { Diet E) }\end{array}$ \\
\hline Yellow Corn & 11.22 & 11.22 & 11.22 & 11.22 & 11.22 \\
\hline Barley & 15.00 & 10.00 & 10.00 & 10.00 & 10.00 \\
\hline Wheat bran & 23.33 & 18.33 & 18.30 & 8.33 & 8.30 \\
\hline Alfalfa hay & 30.12 & 30.12 & 30.10 & 30.12 & 30.10 \\
\hline Soya bean meal & 17.33 & 17.33 & 17.33 & 17.33 & 17.33 \\
\hline Data stone meal & 0.00 & 10.00 & 10.00 & 20.00 & 20.00 \\
\hline Vit. + Min. Premix ${ }^{*}$ & 0.30 & 0.30 & 0.30 & 0.30 & 0.30 \\
\hline Salt $(\mathrm{NaCl})$ & 0.50 & 0.50 & 0.50 & 0.50 & 0.50 \\
\hline Dicalcium Phosphate & 1.20 & 1.20 & 1.20 & 1.20 & 1.20 \\
\hline Limestone & 1.00 & 1.00 & 1.00 & 1.00 & 1.00 \\
\hline Enzyme & 0.00 & 0.00 & 0.05 & 0.00 & 0.05 \\
\hline TOTAL & 100.00 & 100.00 & 100.00 & 100.00 & 100.00 \\
\hline \multicolumn{6}{|l|}{ Chemical analysis } \\
\hline Dry matter & 87.63 & 87.18 & 87.08 & 87.53 & 87.53 \\
\hline Ash & 6.27 & 6.54 & 6.57 & 6.33 & 6.30 \\
\hline Crude protein & 17.69 & 17.31 & 17.36 & 16.87 & 16.75 \\
\hline Crude fat & 2.91 & 3.09 & 3.13 & 3.55 & 3.58 \\
\hline Crude fiber & 12.78 & 13.25 & 13.22 & 14.07 & 14.00 \\
\hline NDF & 37.02 & 37.73 & 37.73 & 38.29 & 38.28 \\
\hline $\mathrm{ADF}$ & 20.67 & 21.65 & 21.65 & 22.43 & 22.42 \\
\hline Hemicellulose & 16.35 & 16.08 & 16.08 & 15.86 & 15.86 \\
\hline Digestible energy & 2542 & 2508 & 2508 & 2480 & 2480 \\
\hline \multicolumn{6}{|c|}{ 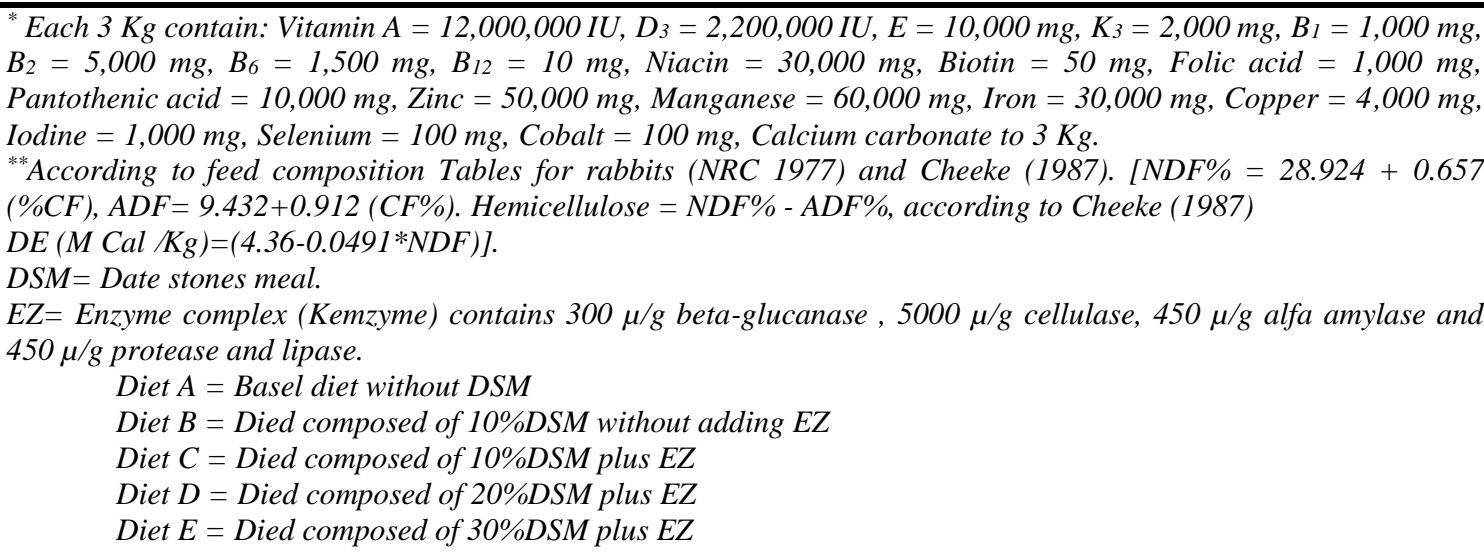 } \\
\hline
\end{tabular}

\section{Statistical analysis}

Data were statistically examined by analysis of variance (ANOVA) according to Snedecor and Chochran (1982) using SPSS system (2006). The differences between means were tested by using Duncan's New Multiple Range test, (Duncan, 1955).

$$
\mathrm{Yij}=\mu+\mathrm{Ti}+\mathrm{eij}
$$

Where: $\mu=$ Overall mean of Yij, $\mathrm{T}=$ Effect of treatment, $\mathrm{i}=(1,2 \ldots$, etc $)$ and $\mathrm{eij}=$ Experimental error. 


\section{RESULTS AND DISCUSSION}

\section{Chemical composition of date stone meal, barley and wheat bran:}

Chemical analysis of date stone meal (DSM), barley and wheat bran are presented in Table (2) chemical analysis of DSM showed that the moisture content was $8.23 \%$ which may be indicating the ability of store to be as untraditional feed stuff for a longtime without any deleterious effects. Also, previous results illustrated that DSM might be considered as a promising source of energy in poultry feed, as it contained about $88.14 \%$ of the energy content of yellow corn. Al-Harthi et al. (2009) and El-Sheikh et al. (2013) reported that dietary date is considered as a good source of energy for poultry. However, the remarkable high contents of CF in DSM (17.94\%) might be considered as a limiting factor in formulating poultry diets (Sawaya et al., 1984) especially regarding the availability of amino acids (Babatunde et al., 1975). The obtained results agree with those analyzed by Soliman et al. (2009); Ibrahim et al. (2010); Masoudi et al. (2011) and El-Sheikh et al. (2013) where they reported nearly same results. Also, Attia and Al-Harthi (2015) showed that the chemical composition of date waste suggests that it's a suitable source of nutrients and energy for chickens. The differences in chemical composition of date stone in comparison with the data shown in literature could be attributed to the variety, maturation stage, dryness degree and agronomic conditions.

Table (2): The chemical analysis of the date stone, barley, and wheat bran.

\begin{tabular}{lcccccc}
\hline Composition & Moisture & Crude protein & Ether extract & Crude fiber & Ash & Nitrogen free extract \\
\hline DSM & 8.23 & 6.38 & 7.41 & 17.94 & 1.42 & 58.62 \\
Barley & 12.20 & 10.30 & 1.97 & 4.60 & 2.22 & 68.71 \\
Wheat bran & 11.50 & 14.97 & 3.40 & 9.48 & 4.92 & 58.40 \\
\hline
\end{tabular}

\section{The apparent digestibility coefficient of the nutrients:}

The results for apparent digestibility coefficient of nutrients of NZW rabbits as affected by supplementation of EZ to diets contain DSM are presented in Table (3).

Table (3): Apparent nutrients digestibility coefficient of NZW rabbits fed diets containing different levels of date stones meal (DSM).

\begin{tabular}{lccccccc}
\hline \multirow{2}{*}{ Item } & Group & Group & Group & Group & Group & \multirow{2}{*}{ SEM } & Sig. \\
\hline Dry matter & 1 & 2 & 3 & 4 & 5 & & \\
Organic matter & $61.7 \mathrm{~b}^{\mathrm{c}}$ & $59.8 \mathrm{~b}^{\mathrm{c}}$ & $68.0^{\mathrm{a}}$ & $59.1^{\mathrm{c}}$ & $63.2^{\mathrm{b}}$ & 1.156 & 0.002 \\
Crude protein & $65.1^{\mathrm{abc}}$ & $62.8^{\mathrm{bc}}$ & $68.1^{\mathrm{a}}$ & $60.5^{\mathrm{c}}$ & $65.5^{\mathrm{ab}}$ & 1.492 & 0.019 \\
Crude Fiber & $72.2^{\mathrm{a}}$ & $67.5^{\mathrm{ab}}$ & $73.9^{\mathrm{a}}$ & $63.6^{\mathrm{b}}$ & $72.3^{\mathrm{a}}$ & 2.106 & 0.014 \\
Neutral detergent fiber & $42.4^{\mathrm{a}}$ & $36.6^{\mathrm{ab}}$ & $41.0^{\mathrm{ab}}$ & $33.1^{\mathrm{b}}$ & $42.7^{\mathrm{a}}$ & 2.64 & 0.045 \\
Acid Detergent Fiber & $35.1^{\mathrm{bc}}$ & $29.4^{\mathrm{cd}}$ & $41.3^{\mathrm{a}}$ & $28.4^{\mathrm{d}}$ & $36.5^{\mathrm{ab}}$ & 1.97 & 0.001 \\
Ether extract & $31.5^{\mathrm{ab}}$ & $28.0^{\mathrm{bc}}$ & $34.5^{\mathrm{a}}$ & $25.2^{\mathrm{c}}$ & $32.0^{\mathrm{ab}}$ & 1.942 & 0.025 \\
Nitrogen free extract & 46.7 & 45.6 & 47.6 & 43.4 & 45.6 & 2.246 & 0.076 \\
Digestible crude protein (DCP) & $68.7^{\mathrm{b}}$ & $68.1^{\mathrm{b}}$ & $73.5^{\mathrm{a}}$ & $68.1^{\mathrm{b}}$ & $70.3^{\mathrm{b}}$ & 0.761 & 0.003 \\
Total digestible nutrients (TDN) & $56.7^{\mathrm{ab}}$ & $10.9^{\mathrm{bc}}$ & $12.0^{\mathrm{a}}$ & $10.3^{\mathrm{c}}$ & $11.7^{\mathrm{ab}}$ & 0.347 & 0.016 \\
\hline
\end{tabular}

$\overline{a, b}$ Values within a row with different superscripts differ significantly at $P<0.05$.

SEM: Standard error of means.

Group $1=$ Fed diet A (Control) is a basal diet without DSM.

Group $2=$ Fed diet $B$ composed of $10 \%$ DSM without adding enzyme complex (Kemzyme, EZ).

Group $3=$ Fed diet $C$ composed of $10 \%$ DSM plus EZ.

Group $4=$ Fed diet D composed of $20 \%$ DSM without EZ.

Group $5=$ Fed diet $E$ composed of $20 \%$ DSM plus EZ.

The results indicated that EZ supplementation to $10 \%$ and $20 \%$ DSM contained diets significantly $(\mathrm{p}<0.05)$ improved OM, CP, CF, NDF, ADF, TDN and DCP digestibility compared to control diet. 
Furthermore, EZ supplementation to $10 \%$ DSM contained diet resulted in a significant $(\mathrm{p}<0.05)$ greater DM and NFE digestibility than control and other DSM groups. However, difference between the $10 \%$ DSM without EZ and 20\%DSM with EZ groups was not significant in DM, OM, CP, CF, ADF, NFE, TDN and DCP digestibility.

The result showed the adverse effect on digestion coefficient of nutrients by increasing DSM levels, which may be due to the high CF content which in consequence may reduce digestibility and availability of nutrients (El-Sheikh et al., 2013).

El-Deek et al. (2008) and Attia, and Al-Harthi (2015) found that the birds fed diet with $200 \mathrm{~g} / \mathrm{kg}$ date waste was lower protein digestibility than those fed diets with other minimal levels of date waste. Similarly, apparent ash retention significantly $(p<0.05)$ decreased with the inclusion of different concentrations of date waste in broiler diets compared to controls. However, AL-Harthi (2006) found that replacing maize with date waste in broiler diets significantly decreasing CF digestibility. Moreover, ElSheikh et al. (2013) showed that hens fed on the control group led to significantly improved digestibility of OM, CP, EE and NFE than those fed diets with Azzawi date meal, while digestibility of DM and CF were not significantly affected by Azzawi date meal levels. This finding was disagreement with those obtained by Suliman and Moustafa (2008) They found that digestibility of CP, CF and NFE were significantly $(\mathrm{P}<0.05)$ increased for diets containing date pits than control diet. Moreover, Alhomidy et al. (2011) found that digestibility of $\mathrm{EE}, \mathrm{DM}$, and $\mathrm{CP}$ were significantly $(\mathrm{P}<0.05)$ higher in the diet containing 30\% discarded dates than in the control diet in sheep. However, Al-Harthi et al. (2009) revealed that no significant difference in digestibility of $\mathrm{CP}$ among the control and all the studied levels of date waste meal. While the lowest value of CF digestibility was noticed for group fed $16 \%$ and $20 \%$ date waste meal containing diet as compared to that of the control. In addition, incorporating $4 \%$ date waste meal resulted in the highest $(\mathrm{P} \leq 0.05) \mathrm{OM}$ and $\mathrm{EE}$ digestibility compared with those of the other levels of the tested material and that of the control. Improving EE digestibility may be attributed to the improvement in fatty acid profile of date meal (Mahmoud, 2005). However, Mousa (2013) found that incorporate of date pits in the diet at the rate of $20 \%$ did not significantly affect DM, OM, CP, CF and NFE digestibilities. While, increasing the proportion of date pits in the diet to $30 \%$ significantly $(\mathrm{P}<0.05)$ decreased $\mathrm{DM}, \mathrm{OM}, \mathrm{CP}$ and $\mathrm{CF}$ and significantly $(\mathrm{P}<0.05)$ increased $\mathrm{EE}$ digestibilites compared with control.

The present data demonstrated EZ addition improved $(p<0.05)$ digestibility of nutrients at inclusion levels of 10\% and 20\% DSM. This finding was agreement with Deek et al. (2008) They reported that kemzyme supplemented diets numerically increased the digestibility of nutrients. The benefit gained by the kemzyme addition is largely due to the partial degradation of the soluble $\beta$-glucan, which reducing the viscosity of intestinal contents and improving nutrients absorption (Hesselman and Aman, (1986); Rotter et al. (1989). Also, these findings agree with El-Manylawi and El-Banna (2013). They reported that adding Allzyme ${ }^{\circledR}$ SSF to the rabbit diets containing 10 or $20 \%$ DSM led to numerical increases in the digestibilities of most nutrients compared to the control diet. The reduction in digestibility of the DSM experimental diets without EZ could be due to the high level of non-starch polysaccharides (NSPs). Fasiullah et al. (2010) reported that exogenous microbial EZ enhanced digestion of (NSP) breaking down cellulose, hemi-cellulose, pectins and lignified complexes. Thus, leading to improved feed utilization and growth performance. Also, reports by Garcia et al. (2005), Falcao-e-Cunha et al. (2007) and Bawa et al. (2009) showed that EZ supplementation in rabbit diet significantly improved performance and nutrient digestibility. Also, Ibrahim et al. (2010) revealed that the addition of a commercial EZ complex slightly improved digestibility coefficients of DM, CP, CF, EE and NFE of date stone. Abaza and Omara (2011) and El-Kelawy and El-Kelawy (2016) revealed that digestibility coefficient of DM, CP, NFE and DCP were significantly $(\mathrm{P}<0.01)$ higher with rabbits fed multienzymes diet compared with those fed the control diet. The improvement in rabbits performances with multienzymes can be ascribed to improved nutrient supply to the animal (Gracia et al., 2009); to a reduction in digesta viscosity (Cowan, 2002); and to an improvement in the gut absorptive capacity (Wu et al., 2004).

\section{Growth performance:}

Data presented in Table (4) showed the effects of supplementation of EZ to diets contain DSM on growth performance of growing NZW rabbits. The results that the birds fed diet containing 10 and $20 \%$ DSM without EZ supplementation had lower $(\mathrm{p}<0.05)$ BW and BWG. Supplementation of EZ to $10 \%$ DSM contained diets significantly $(\mathrm{p}<0.05)$ increased BW at 8 and 12 weeks of age and BWG in all periods in comparison with control diet. In addition, the groups on the control diet and 10\% DSM with EZ group exhibited significantly $(\mathrm{p}<0.05)$ greater $\mathrm{BW}$ and BWG than the other DSM groups during 
periods 4-8 and 4-12 weeks of age. On the other hand, the groups on 20\% DSM with EZ group showed significantly greater BW and BWG than the 20\% DSM without EZ group.

The negative effects of DSM level on rabbit's performance may be due the low protein level of diets and the high fibre level of DSM. Therefore, reduce the digestibility and availability of nutrients. Similarly, Perez et al. (2000) and Masoudi et al. (2011) indicated that the birds fed diet containing date stone had lower final weight and BWG than control group. This could be because of the high fibre level of DSM and its gritty nature, which diminish digestibility and therefore reduce the availability of nutrients particularly amino acids (Yeong, 1983 and Onwudike, 1986). In addation, Ezieshi and Olomu (2008) found that final BWG of broiler chickens was significantly lower than control when palm kernel meal was included in the diet. Also, Al-Saffar et al. (2013) found that adding date stone to laying diets led to decrease performance. However, El-Sheikh et al. (2013) reported that final BW and BWG were not significantly affected by Azzawi date meal levels. This finding was inconsistency with Vandepopuliere et al. (1995). They found that untreated date stone from 5 to $27 \%$ could be supplemented to broiler diets for improve growth performance. Also, Attia and Al-Harthi (2015) reported that diets containing date waste improved broiler performance while the best performance was gotten when adding $50 \mathrm{~g} / \mathrm{kg}$ of date waste to diet. Tareen et al. (2017) who noted that BW of broiler increased significantly with increasing level of date palm kernel.

The present data demonstrated a BW and BWG response to dietary EZ addition. Generally, Enzyme supplementation improved the growth at inclusion levels of $10 \%$ and $20 \%$ DSM. This may be due to that EZ addition, led to increase digestibility and the availability of nutrients in the low-density diets therefore improved the growth. This finding was agreement with El-Manylawi and El-Banna (2013). They found that this positive impact may be due to the beneficial role of Allzyme ${ }^{\circledR}$ SSF in improving the digestibility of date stones in the experimental diets. Similarly, Soliman et al. (2009) and Ibrahim et al. (2010) noted that adding EZ to diets contain DSM led to improved rabbit's growth performance. Also, Al-Saffar et al. (2013) showed that EZ supplementation improved laying hens' performance which fed diets with different date stone levels. The present results were in concurrence with Ibrahim et al. (2010), Abaza and Omara (2011) and El-Kelawy and El-Kelawy (2016). They reported that EZ mixture supplementation improved BWG of rabbits. Enzyme mixture could support the endogenous EZ of the poultry \& rabbits (amylase and protease), break down some components of cell wall, which cannot be broken down into absorbable nutrients by endogenous EZ (Tawfeek, 1996 and Tabook et al. 2006), reduced nutrient entrapment and releasing other nutrients like minerals (Al-Harthi et al., 2009; Soliman et al., 2009; Ibrahim et al., 2010 and Attia et al., 2012; Attia et al., 2014a and 2014b), which improved the growth performance.

Table (4): Growth performance of NZW rabbits fed diets containing different levels of date stones meal (DSM).

\begin{tabular}{lccccccc}
\hline Item & Group 1 & Group 2 & Group 3 & Group 4 & Group 5 & SEM & Sig. \\
\hline Body weight (g) at: & & & & & & & \\
4 weeks & 492 & 496 & 489 & 490 & 486 & 6.31 & 0.842 \\
8 weeks & $1045^{\mathrm{a}}$ & $966^{\mathrm{b}}$ & $1054^{\mathrm{a}}$ & $930^{\mathrm{c}}$ & $975^{\mathrm{b}}$ & 7.85 & 0.008 \\
12 weeks & $1885^{\mathrm{a}}$ & $1731^{\mathrm{c}}$ & $1898^{\mathrm{a}}$ & $1656^{\mathrm{d}}$ & $1790^{\mathrm{b}}$ & 18.6 & 0.001 \\
Body weight gain (g) from: & & & & & & \\
4-8 weeks & $553^{\mathrm{a}}$ & $470^{\mathrm{c}}$ & $565^{\mathrm{a}}$ & $440^{\mathrm{d}}$ & $489^{\mathrm{b}}$ & 4.93 & 0.002 \\
8-12 weeks & $841^{\mathrm{a}}$ & $765^{\mathrm{b}}$ & $844^{\mathrm{a}}$ & $726^{\mathrm{c}}$ & $815^{\mathrm{a}}$ & 10.79 & 0.005 \\
4-12weeks & $1393^{\mathrm{a}}$ & $1235^{\mathrm{c}}$ & $1409^{\mathrm{a}}$ & $1166^{\mathrm{d}}$ & $1304^{\mathrm{b}}$ & 13.92 & 0.006 \\
\hline
\end{tabular}

$\overline{a, b}$ Values within a row with different superscripts differ significantly at $P<0.05$.

SEM: Standard error of means.

Group $1=$ Fed diet A (Control) is a basal diet without DSM.

Group 2= Fed diet B composed of 10\% DSM without adding enzyme complex (Kemzyme, EZ).

Group 3= Fed diet $C$ composed of $10 \%$ DSM plus EZ.

Group $4=$ Fed diet D composed of $20 \%$ DSM without EZ.

Group $5=$ Fed diet E composed of $20 \%$ DSM plus EZ.

\section{Feed intake and feed conversion ratio:}

Data presented in Table (5) showed the effects of supplementation of EZ to diets contain DSM on FI, feed conversion ratio of growing NZW rabbits. The results were indicated that the rabbits fed diet containing 10 and 20\% DSM without EZ supplementation had lower FI and less feed conversion ratio 
than control group. Supplementation of EZ to $10 \%$ DSM contained diets significantly $(\mathrm{p}<0.05)$ increased FI and improved feed conversion ratio in all periods compered to control diet. In addition, the groups on the control diet and 10\% DSM with EZ group exhibited significantly $(\mathrm{p}<0.05)$ greater FI and better feed conversion ratio than the other DSM groups during periods 4-8 and 4-12 weeks of age. On the other hand, the groups on $20 \%$ DSM with EZ group showed significantly greater FI and better feed conversion ratio than the $20 \%$ DSM without EZ group.

Table (5): Feed intake and feed conversion ratio of NZW rabbits fed diets containing different levels of date stones meal (DSM).

\begin{tabular}{lccccccc}
\hline Items & Group 1 & Group 2 & Group 3 & Group 4 & Group 5 & SEM & Sig. \\
\hline Feed intake (g/day) from: & & & & & & \\
4-8 weeks & $1747^{\mathrm{a}}$ & $1617^{\mathrm{c}}$ & $1758^{\mathrm{a}}$ & $1583^{\mathrm{d}}$ & $1655^{\mathrm{b}}$ & 1.30 & 0.005 \\
$8-12$ weeks & $3518 \mathrm{a}$ & $3503^{\mathrm{a}}$ & $3561^{\mathrm{a}}$ & $3267^{\mathrm{b}}$ & $3498^{\mathrm{a}}$ & 30.88 & 0.019 \\
4-12weeks & $5264 \mathrm{a}$ & $5120^{\mathrm{b}}$ & $5319^{\mathrm{a}}$ & $4850^{\mathrm{c}}$ & $5153^{\mathrm{b}}$ & 37.21 & 0.018 \\
Feed conversion ratio (g feed/g gain) from age: & & & & & \\
4-8 weeks & $3.16^{\mathrm{c}}$ & $3.44^{\mathrm{b}}$ & $3.12^{\mathrm{c}}$ & $3.60^{\mathrm{a}}$ & $3.39^{\mathrm{b}}$ & 0.025 & 0.002 \\
8-12 weeks & $4.19^{\mathrm{d}}$ & $4.59^{\mathrm{a}}$ & $4.22^{\mathrm{d}}$ & $4.51^{\mathrm{b}}$ & $4.30^{\mathrm{c}}$ & 0.02 & 0.007 \\
4-12weeks & $3.78^{\mathrm{c}}$ & $4.15^{\mathrm{a}}$ & $3.78^{\mathrm{c}}$ & $4.16^{\mathrm{a}}$ & $3.96^{\mathrm{b}}$ & 0.016 & 0.001 \\
\hline
\end{tabular}

${ }^{a, b}$ Values within a row with different superscripts differ significantly at $P<0.05$.

SEM: Standard error of means.

Group $1=$ Fed diet A (Control) is a basal diet without DSM.

Group $2=$ Fed diet $B$ composed of 10\% DSM without adding enzyme complex (Kemzyme, EZ).

Group $3=$ Fed diet $C$ composed of $10 \%$ DSM plus EZ.

Group $4=$ Fed diet D composed of $20 \%$ DSM without EZ.

Group 5= Fed diet $E$ composed of $20 \%$ DSM plus EZ.

The negative effects of DSM level on rabbits feeding are similar to the reports by Masoudi et al. (2011). They revealed that fed date pits to broiler chickens diets decreased FI and increased FCR which indicated poor utilization of diets by the birds, probably due to higher CF levels of the diets containing date stone compared with the control diet. Similarly, Deek et al. (2008) found that date waste meal addition in diets impaired FCR of Lohmann White Layers. Also, Attia and Al-Harthi (2015) showed that chicken fed date waste at $50 \mathrm{~g} / \mathrm{kg}$ lowest FI than control. This finding was dissension with those obtained by Ezieshi and Olomu (2008) and Tareen et al. (2017). They showed that date palm kernel addition in diets improved FCR of broilers considerably, which was mainly associated with lower FI to produce highest BW.

The present data demonstrated that enzyme supplementation increased FI and improved FCR at inclusion levels of $10 \%$ and $20 \%$ DSM. The increase in FI by EZ supplementation led to increased CP intake and associated essential amino acids that were necessary for the optimum performance of birds (Masoudi et al., 2011). These observations coincided with those reported by Al-Saffar et al. (2013) showed that EZ supplementations improved FCR of laying hens fed diets with different date stone levels. Also, Deek et al. (2008) found that overall kemzyme addition improved FCR by about 5.24\% over the kemzyme un-supplemented diets. Furthermore, Ibrahim et al., 2010 indicated that $50 \%$ replacement of yellow corn ground date stone (with or without kemzyme) significantly improved FCR of male rabbits during the trial period. Similarly, Abaza and Omara (2011) and El-Kelawy and El-Kelawy (2016) reported that multienzymes supplementation increased FI and improved FCR of rabbits.

\section{Economic efficiency and production index:}

Data presented in Table (6) showed the effects of supplementation of EZ to diets contain DSM on economic efficiency and production index of growing NZW rabbits. The results indicated that the rabbits fed diet containing 10 and 20\% DSM without EZ supplementation had less economic efficiency and production index than control group. On the other hand, the birds fed diet containing 10 without EZ and $20 \%$ DSM with or without EZ had lower feed cost than control and 10\% DSM with EZ supplementation groups. Supplementation of EZ to $10 \%$ DSM contained diets significantly $(p<0.05)$ improved total revenue, net revenue, economic efficiency and production index in all periods compared to control diet. In addition, the groups on the control diet and 10\% DSM with EZ group exhibited significantly better total revenue, net revenue, economic efficiency and production index than the other DSM groups. On the 
other hand, the groups on 20\% DSM with EZ group showed significantly better total revenue, net revenue, economic efficiency and production index than the 20\% DSM without EZ group.

Table (6): Economic efficiency and production index of NZW rabbits fed diets containing different levels of date stones meal (DSM).

\begin{tabular}{lccccccc}
\hline Item & Group 1 & Group 2 & Group 3 & Group 4 & Group 5 & SEM & Sig. \\
\hline Feed cost & $15.79^{\mathrm{a}}$ & $14.90^{\mathrm{b}}$ & $15.55^{\mathrm{a}}$ & $13.68^{\mathrm{c}}$ & $14.60^{\mathrm{b}}$ & 0.110 & 0.001 \\
Total revenue & $39.70^{\mathrm{a}}$ & $34.62^{\mathrm{c}}$ & $39.96^{\mathrm{a}}$ & $33.12^{\mathrm{d}}$ & $35.80^{\mathrm{b}}$ & 0.372 & 0.002 \\
Net revenue & $13.91^{\mathrm{a}}$ & $9.72^{\mathrm{c}}$ & $14.41^{\mathrm{a}}$ & $9.44^{\mathrm{c}}$ & $11.20^{\mathrm{b}}$ & 0.264 & 0.007 \\
Economic efficiency & $53.87^{\mathrm{b}}$ & $38.97^{\mathrm{d}}$ & $56.37^{\mathrm{a}}$ & $39.85^{\mathrm{d}}$ & $45.47^{\mathrm{c}}$ & 0.846 & 0.001 \\
Production index & $62.56^{\mathrm{a}}$ & $46.39^{\mathrm{c}}$ & $63.30^{\mathrm{a}}$ & $44.23^{\mathrm{d}}$ & $50.58^{\mathrm{b}}$ & 0.668 & 0.004 \\
\hline
\end{tabular}

$\overline{a, b}$ Values within a row with different superscripts differ significantly at $P<0.05$.

SEM, Standard error of mean's.

Group $1=$ Fed diet A (Control) is a basal diet without DSM.

Group $2=$ Fed diet B composed of $10 \%$ DSM without adding enzyme complex (Kemzyme, EZ).

Group $3=$ Fed diet $C$ composed of $10 \%$ DSM plus EZ.

Group $4=$ Fed diet D composed of $20 \%$ DSM without EZ.

Group 5= Fed diet E composed of $20 \%$ DSM plus EZ.

The present results were indicated that diets containing DSM had less economic efficiency, but lower feed cost than control. This finding was agreement with Abd El-Rahman et al. (2003); Abou El-Naser and El-Kerdawy (2003); Masoudi et al. (2010) and Mousa (2013). Thay reported that the total cost of the diet decreased by increasing the portions of date pits in diets. Also, This findings are in agreement with Gaber et al. (2012) and El-Manylawi and El-Banna (2013). These decreased in feed cost may be attributed to the inclusion of DSM in the diets due to its low price. Furthermore, El-Sheikh et al. (2013) showed that hens fed diet with 40\% Azzawi date meal had significantly greater economical efficiency than the control group. Improvement of the economical efficiency values may be attributed to decreased price of Azzawi date meal and the highest BW. However, Toson et al. (1995) reported that the inclusion of DSM to replace up to $20 \%$ of rabbits basal diet has no adverse impact on economic efficiency of rabbits. This findings are in contradiction with Tareen et al. (2017). They noted that the inclusion of date palm kernel in broilers basal diet increased net profit.

The present data demonstrated EZ supplementation improved economic efficiency and production index at inclusion levels of $10 \%$ and $20 \%$ DSM. This finding was agreement with El-Manylawi and ElBanna (2013) who revealed that adding Allzyme ${ }^{\circledR}$ SSF to the rabbit diets under each experimental tested DSM (10 or $20 \%$ ) improved the economic efficiency. Furthermore, Ibrahim et al. (2010) demonstrated that DSM could be utilized rather than yellow corn (50\% substitution) either without or with special kemzyme addition, which lead to best economic efficiency. Also, Abaza and Omara (2011) found that economic efficiency of rabbits was better with EZ addition in diets than without EZ addition. Similarly, El-Kelawy and El-Kelawy (2016) who reported that multienzymes supplementation improved economic efficiency and production index of rabbits.

\section{CONCLUSION}

It could be postulated that date stone meal can be inclusion in rabbit diets up to $20 \%$ with adding EZ without adverse effect on rabbit performance and up to $10 \%$ with adding EZ to achieve good performance and economic efficiency comparable to control group, under Egyptian environmental conditions.

\section{REFERENCES}

Abaza, M. and M. E. Omara (2011). Effect of dietary corn cobs and EZ supplementation on growing rabbits performance. Journal of Production and Development 16(3): 507-527. 
Abd El-Rahman, G. A.; H. M. Abou El-Nasr; M. S. Ayyat; A.M. Fayed and M. S. Nassar (2003). Utilization of some agro- industrial by products in fattening lambs on the natural ranges in south valley. Egyptian Journal Nutrition and Feeds, 6 (Special Issue) , 851-865.

Abdollahi, M.R.; B.J. Hosking; D. Ning and V. Ravindran (2016). Influence of palm kernel meal inclusion and exogenous enzyme supplementation on growth performance, energy utilization, and nutrient digestibility in young broilers. Asian Australas. Journal Animal Science, 29(4): 539-548.

Abou El-Nasr, H. M. and D. M. A. El-Kerdawy (2003). Effect of complete replacement of the common feed mixture by agro - industrial by products on performance of growing lambs under desert conditions of Egypt. Egyptian Journal Nutrition and Feeds, 6 (Special Issue): 803-810.

Al-Harthi, M.A. (2006). The influence of date waste meal supplemented with enzymes, probiotics or their combination on broiler performance. Egyptian Poultry Science, 26:1031-1055.

Al-Farsi, M.; C. Alasalvar; M. Al-Abid; K. Al-Shoaily; M. Al-Amry and F. Al-Rawahy (2007). Compositional and functional characteristics of dates, syrups and their by-products. Food Chem., 104, 3, 943-947.

Al-Harthi, M. A.; A. A. El-Deek; H. M. Yakout and M. AL-Refaee (2009). The nutritive value of date waste meal as a feedstuff for Lohmann Brown pullets and layers. Journal Poultry Science, 46:303312.

Al-Hiti, M. K. (1978). Date waste without stones in broiler diets. British Poultry Science, 19:17-19.

Alhomidy, S.N.; S. Basmaeil; A. M. Al-Owaimer; A.M. El-Waziry and M. Koohmaraie (2011). Effect of feeding different amount of discarded dates on growth and efficiency of digestion in sheep. Australian Journal Basic and Applied Science, 5: 636-640.

Al-Saffar, A.A.; Y.A. Attia; M.B. Mahmoud; H.S. Zewell and F. Bovera (2013). Productive and reproductive performance and egg quality of laying hens fed diets containing different levels of date pits with enzyme supplementations. Trop. Animal Health and Production, 45, 327-334.

AOAC (2004). Association of Official Analytical Chemists International: Official Methods of Analysis of AOAC International. 18th edition, AOAC International, Gaithersburg, MD, USA.

Attia, Y.A. and M.A. Al-Harthi (2015). Effect of supplementation of date waste to broiler diets on performance, nutrient digestibility, carcass characteristics and physiological parameters. European Poultry Science, Vol. 79. 10.1399/eps.2015.91.

Attia, Y.A.; W.S. El-Tahawy; A.E. Abd El-Hamid; S.S. Hassan; A. Nizza and M. I. El-Kelaway (2012). Effect of phytase with or without multienzyme supplementation on performance and nutrient digestibility of young broiler chicks fed mash or crumble diets. Italian Journal of Animal Science, 11: 303-308.

Attia, Y.A.; W.S. El-Tahawy; A. E. Abd El-Hamid; A. Nizza; F. Bovera; M. A. Al-Harthi and M.I. ElKelawy (2014a). Effect of feed form, pellet diameter and enzymes supplementation on growth performance and nutrient digestibility of broiler during days 21-37 of age. Archiv Tierzucht, 57(34): $1-11$

Attia, Y.A.; W.S. El-Tahawy; A. E. Abd El-Hamid; A. Nizza; M.I. El-Kelawy; M.A. Al-Harthi and F. Bovera (2014b). Effect of feed form, pellet diameter and enzymes supplementation on carcass characteristics, meat quality,blood plasma constituents and stress indicators of broilers. Archiv Tierzucht, 57(30): 1-14.

Bawa, G. S.; O. P. Sani and T. S. Olugbemi (2009). Effects of varying levels of maize cobs supplemented with Allzyme ${ }^{R}$ or Maxigrain ${ }^{\circledR}$ on growth performance and carcass characteristics of young rabbits. Proceedings of the $34^{\text {th }}$ Conference of the Nigerian Society of Animal production (NSAP), held at University of Uyo, Akwa Ibom State Nigeria from March $15^{\text {th }}-18$ th, pp. 156-158.

Cheeke, P. R.; N. Patton and G. S. Templton (1982). Rabbit Production. 5th Edition. The interstate printers and Publishers. Danville 11.

Cheeke, P.R. (1987). Digestive physiology. In: Rabbit feeding and nutrition. Orlando: Academic Press; p. 15-33. http://dx.doi.org/10.1016/B978-008-057078-5.50008-X.

Cowan, W.D. (2002). The influence of phytase on amino acid digestibility in broiler diets. In: McNab, J. 


\section{El-Kelawy et al.}

M. and Boorman, K. N. (Eds), Poultry feedstuffs, supply, composition and nutritive value. Poultry Science Symposium Series Vol. 26. CABI, Wallingford, pp. 386.

Duncan, D.B. (1955). Multiple range and multiple F- test Biometerics, 11: 1-42.

El-Adawy, M.M.; B. E. Borhami; A. Z. M. Salem and A.E. Abo-Zeid (2005). Rabbit growth performance as affected by phytase and biogen supplementation for linseed meal diets. The 4th Inter. Con. On Rabbit Prod. In Hot Climate Sharm El-Sheikh, Egypt, 351-364.

El-Deek, A. A.; M. A. Al-Harthi and H. M. Yakout (2008). Use of enzymes to supplement diets containing date waste meal for Lohmann White layers.International Journal of Poultry Science, 397407.

El-Kelawy, H. M. and M. I. El-Kelawy (2016). Impact of dietary supplementation with multi enzyme and/or probiotic on growth performance, nutrients digestibility and blood constituents of growing rabbits. Egyptian Journal Nutrition and Feeds, 19 (2): 313-323.

El-Manylawi, M. A. and H. M. El-Banna (2013). Effect of feeding date stone meal supplemented with Allzyme ${ }^{\circledR}$ on performance of growing New Zealand Rabbits. Egyptian Journal Animal Production, 50(2):103-109.

El-Sheikh, S. E. M.; N. A. Al-Shokiry; A. A. Salama and R.E. Khidr (2013). Utilization of Azzawi date meal in local laying hen diets. Egyptian Poultry Science, 33 (4): (1115-1127).

Ezieshi, E.V. and J.M. Olomu (2008). Nutritional evaluation of palm kernel meal types: 2. Effects on live performance and nutrient retention in broiler chickens diets. African Journal of Biotechnology, 7:1171-1175.

Falcao-e-Cunha, L.; L. Castro-Solla; L. Maertens; M. Marounek; V. Pinheiro; J. Freire and J.L. Mour (2007). Alternatives to antidote growth promoters in rabbit feeding: A review. World Rabbit Science 15: $127-140$

Fasiullah, M. S.; Z. H. Khandaker; K. M. S. Islam; M. Kamruzzaman and R. Islam (2010). Effect of dietary enzyme supplementation on nutrient utilization and growth performance of rabbit. International Journal of Biological Research, 1(3): 17-21.

FAO (2014). The Food and Agriculture Organisation of the United Nations, http://www.fao.org/neareast/news/view/en/c/465781/

Gaber, M. M.; E. H. Labib; E. A. Omar; M. A. Zaki and A. M. Nour (2012). Effect of Partially Replacing Corn Meal by Date Stone on Growth Performance in Nile Tilapia (Oreockromis Niloticus) Fingerlings, Diets Supplemented with Digestarom®. Open Access Scientific Reports, 1(10):1-5

Garcia, A.I.; J. Garcia; E. Corrent; S. Chamorro; P. Garcia-Rebollar; C. De Blas and R. Carabano (2005). Effet de l'age du lapin, de la source de protein et de l'utilisationd' enzymessur les digestibilities apparentness de la matiereseche et de la protein brute sur un aliment lapin. In Proc.: ll'emesJournees de la Recherche Cunicole, Paris, France, 197-200

Gracia, M.I.; R. Lazaro; M.A. Latorre; P. Medel; M.J. Aranibar; E. Jiménez-Moreno and G.G. Mateos (2009). Influence of enzyme supplementation of diets and cooking-flaking of maize on digestive traits and growth performance of broilers from 1-21 days of age. Animal Feed Science and Technology, 150: $303-315$.

Hesselman, K. and A. Aman (1986). The effect of Beta-glucanase on the utilization of starch and nitrogen by broiler chicken fed on barley low on viscosity. Animal Feed Science Technology 15:83-93.

Ibrahim, M. R.; H. M. El-Banna and M. A. El- Manylawi (2010). Evaluating utilization of ground date stone meal with or without kemzyme in the diets of growing New Zealand rabbits. IV International Date Palm Conference, 15-17 March, 2010, Abu Dubi, UAE. Acta Hort. (ISHS) 882:691-697.

Mahmoud, M. B. M. (2005). Improving the utilization of date stone as untraditional feedstuff in poultry diet. Ph.D Thesis, Faculty of Agriculture (Saba Basha), Alexandria University.

Masoudi, A.; M. Bojarpour; M. Chaji; M. Eslami and Kh. Mirzadeh (2010). Economic value of date Pits replaced with maize in broiler chicken diet. Journal of Animal and Veterinary Advances, 9:15781581.

Masoudi, A.; M. Chaji; M. Bojarpour and Kh. Mirzadeh (2011). Effects of different levels of date pits on performance, carcass characteristics and blood parameters of broiler chickens, Journal of Applied 
Animal Research, 39(4):399-405.

Mousa, M.R. M. (2013). Growth performance of rabbits fed date pits in north Sinai. Journal Animal and Poultry Production, Mansoura University ,4 (5): 321 - 333

NRC (1977). National Research Councli. Nutrition Requirements of Domestic animals. Nutrient Requirements of rabbits. $2^{\text {nd }}$ Rev. Ed. National Academy of Science, Washington, D.C.

Onwudike, O. C. (1986). Palm kernel meal as a feed for poultry,1. Composition of palm kernel and availability of its amino acids to chicks. Animal Feed Science and Technology, 16:179-186.

Perez, J. F.; A. G. Gernat and J.G. Murillo (2000). The effect of different levels of palm kernel meal in layer diets. Poultry Science, 79: 77-79.

Rotter, B.A.; R.R. Marquardt; W. Guenter; C. Biliaderis and C.W. Newman (1989). In vitro viscosity measurement of barley extracts as predictors of growth responses in chicks fed barley-based diets supplemented with a fungal enzyme preparation. Canadian Journal Animal Science, 69: 431-439.

Sawaya, W. N.; J. K. Khalid and W.J. Safi (1984). Chemical composition and nutritional quality of date seeds. Journal Food Science, 49: 617-619.

Shaw, A. L.; J. P. Blake and R. W. Gordon (2010). Evaluation of commercial phytase enzymes on performance and tibia-breaking strength of male broiler chicks. The Journal of Applied Poultry Research, 19:415-421.

Snedecor, G.W. and W.G. Cochran (1982). Statistical Methods. 7th Edition, Iowa State University, Press Ames, USA.

Soliman, A. Z. M.; R. E. Khidr; M. A. F. EL- Manylawi and S. E. M. El-Sheikh (2009). Chemical and biological evaluation of date stone meal as an untraditional feedstuff in growing rabbit diets. The 5 th International Poultry Conference 10-13 March 2009. Taba- Egypt (852-863).

SPSS (2006). SPSS User's Guide Statistics Version 10. Copyright SPSS Inc., USA.

Suliman, A. I. A. and S. M. S. Moustafa (2008). Effect of ground date seeds as a partial replacer of ground maize on nitrogen metabolism and animal performance of sheep. Journal Agriculture Science, Mansoura University, 33 (3): 1735-1744.

Sundu, B.; A. Kumar and J. Dingle (2006). Palm kernel meal in broiler diets: Effect on chicken performance and health. Worlds Poultry Science Journal, 62(2): 316-325.

Tabook, N.M.; I.T. Kadim; O. Mahgoub and W. Al-Marzooq (2006). The effect of date fibre supplemented with an exogenous enzyme on the performance and meat quality of broiler chickens. British Poultry Science, 47, 73-82.

Tareen, M.H.; R. Wagan; F.A. Siyal; D. Babazadeh; Z.A. Bhutto; M.A. Arain and M. Saeed (2017). Effect of various levels of date palm kernel on growth performance of broilers, Veterinary World, 10(2): 227-232.

Tawfeek, M.I. (1996). Effect of feeding system and supplemented diet with Kemzyme on growth, blood constituents, carcass traits and reproductive performance in rabbits, under intensive production conditions, Egyptian Journal of Rabbit Science, 6 (1): 2137-2140.

Toson, M.; A. El-Bogdady and A. Osman (1995). Effect of using date stone meal in rabbit diets. Journal Agriculture Science, Mansoura University, 20:2160-2169.

Vandepopuliere, J. M.; Y.M. Al-Yousef and J. J. Lyos (1995). Date and date pits as ingredients in broiler starting and coturnix quail breeder diets. Poultry Science, 74:1134 -1142.

Wu, Y.B.; V. Ravindran; D.G. Thomas; M.J. Birtles and W.H. Hendriks (2004). Influence of phytase and xylanase individually or in combination on performance, apparent metabolisable energy, digestive tract measurements and gut morphology in broilers fed wheat-based diets containing adequate level of phosphorus. British Poultry Science, 45:78-84.

Yeong, S.W. (1983). Amino acid availability of palm kernel cake, palm oil sludge and sludge fermented product (Prolima) in studies with chickens. MARDI Research Bulletin, 11:84-88.

Zanu, H.K.; J. Abangiba; W. Arthur-Badoo; A.D. Akparibo and R. Sam (2012) Laying chickens' response to various levels of palm kernel cake in diets. International Journal Livestock Production, 


\title{
El-Kelawy et al.
}

3(1): $12-16$.

Zeweil, H.S. (1996). Enzyme supplements to diets growing Japanese quails Egyptian. Poultry Science Journal, 16 (III): 535-557.

\section{تأثير مسحوق نوى البلح مع أو بدون إضافة الإنزيمات على الأداء الإنتاجي وهضم العناصر الغذائية والكفاءة الاقتصادية للأرانب النامية}

\author{
محمود إبراهيم الكيلاوي1 ، علي سعيد الثافعي2 2 و حاتم عبد القادر حمدن3 \\ 1 قسم إنتاج الدو/جن ـ كلية الزراعة ـ جامعة الوادي الجبلي- مصر.

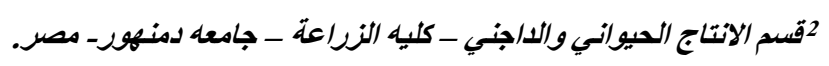 \\ 3قسم إلاتتاج الجيوانسى ـ كلية الزراعة - جامعة الوادي الجبلي- مصر.
}

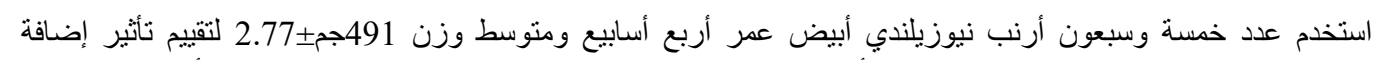

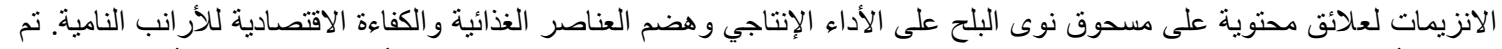

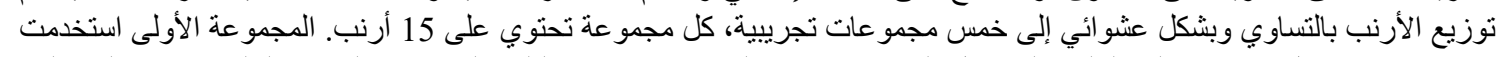

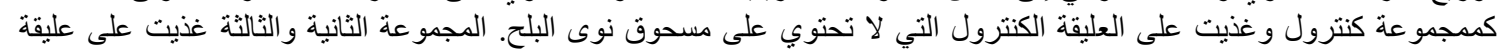

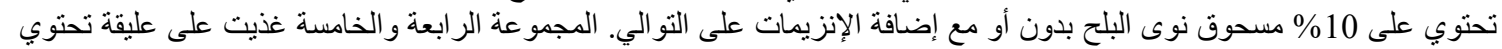

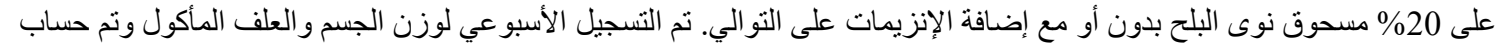

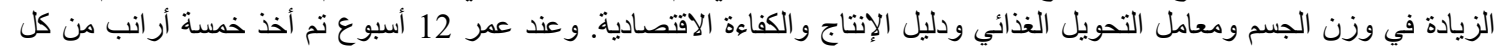

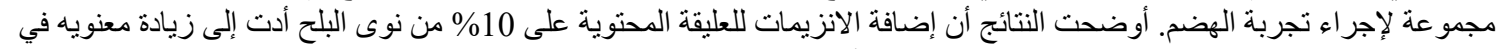

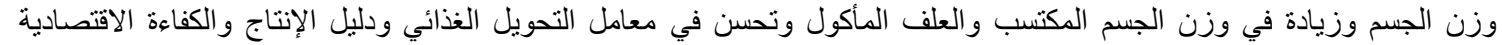

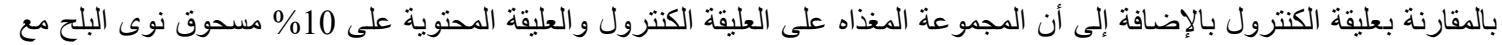

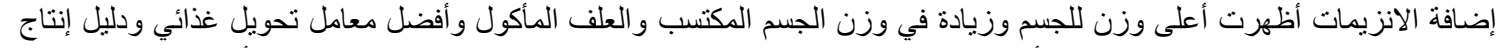

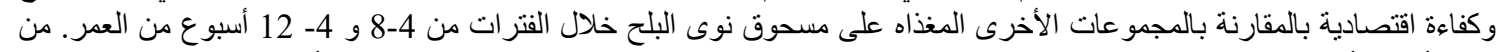

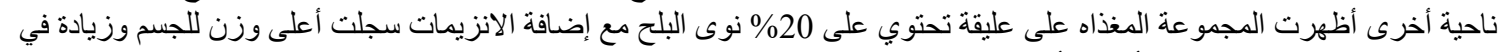

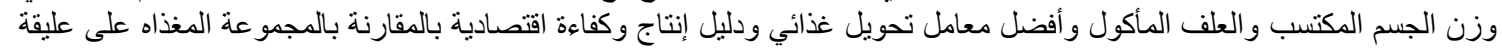

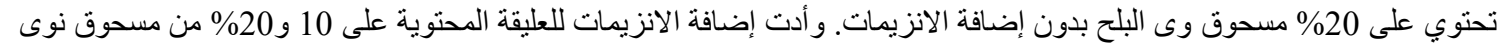

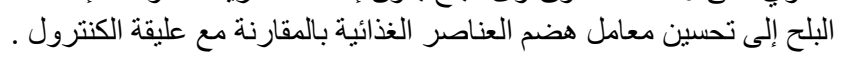

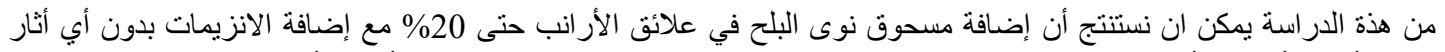

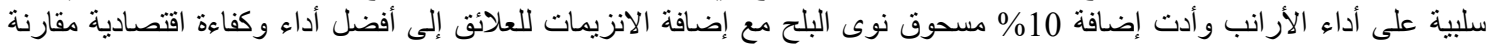

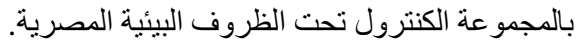

